\title{
KAMPUNG ORGANIK SEBAGAI MODEL PENDIDIKAN LINGKUNGAN BERBASIS MASYARAKAT BAGI ANAK USIA DINI DI KOTA SEMARANG
}

\author{
Sukirman $^{1}$, Rafika Bayu Kusumandari ${ }^{2}$ \\ ${ }^{1,2}$ Fakultas Ilmu Pendidikan, Universitas Negeri Semarang \\ Email: sukirman_fip55@yahoo.co.id
}

\begin{abstract}
Organic village is the designation for the urban / rural are developing environmental management where whole communities to manage the environment by planting organic crops. Even they develop dengue mosquito eradication in a way that is natural to plant crops that are not favored by mosquitoes. Referring to the objectives to be achieved, the research program was designed with a "Research and Development", meaning that a program of research followed by development program for repair or improvements. To produce a prototype Organic Village Environmental Education As Model For Community-Based Early Childhood, taken systematic steps in the form of the process of action, reflection, evaluation and innovation by applying qualitative research methods, descriptive, development, experimentation and evaluation. This study aims to gain in-depth overview of the Organic Village Environmental Education As Model For Community-Based Early Childhood. Village of Krobokan becoming a pilot village for urban areas for environmental regulation. Every citizen of organic crops and other useful plants such as mosquito repellent plants, fruit trees, etc. In addition, it is promoting recycling bins, especially organic waste that leaves of trees that have fallen. The leaves are processed into compost, but before it becomes compost. These leaves, crushed in advance by using a grinding machine garbage. It is intended to order the leaves into small pieces, so that when inserted into the barrel composer of the leaf pieces faster into fertilizer. The finished compost directly used to fertilize plants that live in stalls in the village Krobokan. For environmental education in early childhood, conducted in three schools namely TK Pembina State Semarang, Semarang Lab School kindergarten and kindergarten An Nur Semarang. The third school to apply the concept of habituation and role models as well as cooperation with parents. Keywords: Organic Village, Environmental Education, Early Childhood
\end{abstract}

\begin{abstract}
Abstrak. Desa organik adalah sebutan untuk perkotaan / pedesaan sedang mengembangkan manajemen lingkungan di mana seluruh masyarakat untuk mengelola lingkungan dengan menanam tanaman organik. Bahkan mereka mengembangkan pemberantasan nyamuk dengue dengan cara alami untuk menanam tanaman yang tidak disukai oleh nyamuk. Mengacu pada tujuan yang ingin dicapai, program penelitian dirancang dengan "Penelitian dan Pengembangan", yang berarti bahwa program penelitian diikuti oleh program pengembangan untuk perbaikan atau perbaikan. Untuk menghasilkan prototipe Pendidikan Lingkungan Desa Organik Sebagai Model Untuk Anak Berbasis Anak Usia Dini, diambil langkah sistematis dalam bentuk proses tindakan, refleksi, evaluasi dan inovasi dengan menerapkan metode penelitian kualitatif, deskriptif, pengembangan, eksperimen dan evaluasi. Penelitian ini bertujuan untuk memperoleh gambaran mendalam tentang Pendidikan Lingkungan Desa Organik Sebagai Model Untuk Anak Usia Dini Berbasis Komunitas. Desa Krobokan menjadi desa percontohan untuk daerah perkotaan untuk pengaturan lingkungan. Setiap warga negara dari tanaman organik dan tanaman berguna lainnya seperti tanaman pengusir nyamuk, pohon buah-buahan, dll. Selain itu, mempromosikan sampah daur ulang, terutama sampah organik yang meninggalkan pohon yang telah jatuh. Daunnya diolah menjadi kompos, tetapi sebelum menjadi kompos. Daun-daun ini, dihancurkan terlebih dahulu dengan menggunakan mesin penggilingan sampah. Hal ini dimaksudkan untuk memesan daun menjadi potonganpotongan kecil, sehingga ketika dimasukkan ke dalam komposer barrel dari potongan daun lebih cepat menjadi pupuk. Kompos yang sudah jadi langsung digunakan untuk menyuburkan tanaman yang hidup di warung-warung di desa Krobokan. Untuk pendidikan lingkungan pada anak usia dini, dilakukan di tiga sekolah yaitu TK Pembina Negeri Semarang, TK Taman Kanak-Kanak Semarang dan TK An Nur Semarang. Sekolah ketiga menerapkan konsep habituasi dan model peran serta kerja sama dengan orang tua.
\end{abstract}

Kata Kunci: Desa Organik, Pendidikan Lingkungan, Anak Usia Dini

\section{PENDAHULUAN}

Pendidikan lingkungan adalah sebuah proses yang bertujuan dalam membangun populasi dunia yang berkesadaran dan memiliki kepedulian terhadap lingkungan secara keseluruhan, serta berbagai problem yang terkait dengannya. Menanamkan pengetahuan, sikap, ketrampilan, motivasi, dan komitmen untuk bekerja secara 
individu dan bersama-sama untuk menemukan penyelesaian terhadap masalah-masalah yang saat ini muncul sekaligus mencegah masalah baru. Pengenalan lingkungan hidup bagi anak usia dini ini bertujuan untuk membangun kesadaran sejak dini agar lebih memperhatikan pentingnya pendidikan terhadap lingkungan hidup. Selain itu akan lebih mendekatkan anak kepada lingkungan alam sehingga lebih cepat berinteraksi menyadarai bahwa alam begitu penting untuk kelangsungan hidup.

Pendidikan pengelolaan lingkungan hidup perlu ditanamkan kepada anak sejak usia dini. Usia dini adalah "usia emas" bagi seseorang, artinya bila seseorang pada masa itu mendapat pendidikan yang tepat, maka ia memperoleh kesiapan belajar yang baik dan salah satu kunci utama bagi keberhasilan belajarnya pada jenjang berikutnya. Anak-anak lebih mudah menginternalisasikan nilai-nilai dan kebiasaan melestarikan lingkungan hidup dibandingkan orang dewasa. Dengan demikian, diharapkan perusakan lingkungan di masa depan dapat dicegah melalui kepedulian lingkungan generasi mendatang. Untuk itu, masyarakat sebagai pengelola lingkungan, harus bisa menanamkan nilai-nilai pendidikan lingkungan hidup bagi anak-anak. Adanya pendidikan lingkungan hidup berbasis masyarakat ini akan memudahkan anak untuk mengenal bagaimana mengelola lingkungan dengan baik. Ruang lingkup yang dipilih pada tingkat pendidikan dasar, yaitu untuk lebih memberikan pengenalan kepada anak mengenai lingkungan dan keanekaragaman alam. Juga sebagai bekal pengetahuan berbasis lingkungan sehingga dapat diterapkan ke masyarakat luas.

Kampung Organik adalah sebutan untuk kelurahan atau desa yang mengembangkan pengelolaan lingkungan dimana seluruh masyarakatnya mengelola lingkungan dengan menanam tanaman organik. Bahkan mereka mengembangkan pemberantasan nyamuk DBD dengan cara alamiah yaitu menanam tanaman yang tidak disukai oleh nyamuk. Selain tidak menimbulkan efek negatif, lingkungan juga menjadi lebih sehat. Tidak hanya menanam tanaman organik, masyarakat juga mengelola sampah. Untuk sampah-sampah organik, mereka olah menjadi pupuk sedangkan untuk sampahsampah plastik, akan diolah sesuai dengan jenis dan bentuk masing-masing. Model pendidikan lingkungan berbasis masyarakat ini diharapkan akan lebih mengena bagi anak-anak usia dini dalam mengelola lingkungan.
Temuan dari penelitian ini diharapkan akan dapat menemukan model pendidikan lingkungan berbasis masyarakat untuk anak usia dini. Ini sejalan dengan renstra Unnes pada topik konservasi pada sub topik pendidikan dan manajemen konservasi.

Berdasarkan latar belakang masalah inilah maka peneliti tertarik untuk meneliti model pendidikan lingkungan berbasis masyarakat untuk anak usia dini di Kota Semarang.

\section{a. Permasalahan yang akan diteliti}

Permasalahan yang akan diteliti dalam penelitian ini adalah bagaimana pengembangan model pendidikan lingkungan berbasis masyarakat untuk anak usia dini di Kota Semarang?

\section{b. Tujuan Khusus}

Sesuai dengan perumusan masalah penelitian, maka tujuan khusus dari penelitian ini adalah mendeskripsikan model pendidikan lingkungan berbasis masyarakat untuk anak usia dini di Kota Semarang.

\section{c. Urgensi Penelitian}

Urgensi penelitian ini adalah :

1) Pendidikan lingkungan adalah sebuah proses yang bertujuan dalam membangun populasi dunia yang berkesadaran dan memiliki kepedulian terhadap lingkungan secara keseluruhan, serta berbagai problem yang terkait dengannya.

2) Pengenalan lingkungan hidup bagi anak usia dini ini bertujuan untuk membangun kesadaran sejak dini agar lebih memperhatikan pentingnya pendidikan terhadap lingkungan hidup.

3) Pendidikan pengelolaan lingkungan hidup perlu ditanamkan kepada anak sejak usia dini. Usia dini adalah "usia emas" bagi seseorang, artinya bila seseorang pada masa itu mendapat pendidikan yang tepat, maka ia memperoleh kesiapan belajar yang baik dan salah satu kunci utama bagi keberhasilan belajarnya pada jenjang berikutnya.

4) Pendidikan lingkungan hidup berbasis masyarakat ini akan memudahkan anak untuk mengenal bagaimana mengelola lingkungan dengan baik.

5) Kampung Organik adalah sebutan untuk Kelurahan Krobokan, Kota Semarang yang seluruh masyarakatnya mengelola lingkungan dengan menanam tanaman organik.

6) Temuan dari penelitian ini diharapkan akan dapat menemukan model pendidikan lingkungan berbasis masyarakat untuk 
anak usia dini. Ini sejalan dengan renstra Unnes pada topik konservasi pada sub topik pendidikan dan manajemen konservasi.

\section{METODE PELAKSANAAN}

\section{a. Desain dan Metode Penelitian}

Mengacu pada tujuan yang ingin dicapai, program penelitian ini dirancang dengan pendekatan "Penelitian dan Pengembangan", artinya suatu program penelitian ditindaklanjuti dengan program pengembangan untuk perbaikan atau penyempurnaan (Arikunto, 1996:9). Untuk menghasilkan suatu prototype Kampung Organik Sebagai Model Pendidikan Lingkungan Hidup Berbasis Masyarakat Bagi Anak Usia Dini, ditempuh langkah-langkah sistematis dalam bentuk proses aksi, refleksi, evaluasi dan inovasi dengan mengaplikasikan metode penelitian kualitatif, deskriptif, pengembangan, eksperimen, dan evaluasi.

Penelitian ini bertujuan untuk mendapatkan gambaran mendalam mengenai Kampung Organik Sebagai Model Pendidikan Lingkungan Hidup Berbasis Masyarakat Bagi Anak Usia Dini. Alasan digunakannya digunakannya metode kualitatif karena sepengetahuan peneliti, tidak ada hasil pengkajian dan penelitian empiris yang secara khusus berkenaan dengan Kampung Organik Sebagai Model Pendidikan Lingkungan Hidup Berbasis Masyarakat Bagi Anak Usia Dini. Oleh karenanya, sebagaimana lazimnya dalam penelitian ilmiah langkah yang ditempuh oleh peneliti adalah melakukan penjajagan (eksplorasi) mengenai objek yang sedang diteliti. Dalam hubungan itu metode kualitatif merupakan salah satu metode penelitian yang menawarkan desain penelitian yang bertujuan eksploratif. Tidak seperti halnya pada desain penelitian eksperimental misalnya pada desain penelitian kualitatif peneliti tidak bertitik tolak dari kerangka pikir tertentu, tetapi membiarkan setting penelitian secara alami/sebagaimana adanya dan berupaya memahami gejala yang ada dengan menempatkan diri pada objek yang sedang diteliti (empati). Alasan lain digunakannya metode kualitatif adalah karena dengan metode kualitatif berbagai gagasan, kepedulian, sikap dan nilai dari sejumlah orang yang sedang diteliti dapat dengan mudah dipahami (Zelker, 1989 dalam Utomo 1997:71).

Data dikumpulkan dari latar yang dialami (natural setting) sebagai sumber data langsung. Pemaknaan terhadap data tersebut hanya dapat dilakukan apabila diperoleh kedalaman atas fakta yang diperoleh. Penelitian ini diharapkan dapat membangun suatu teori secara induktif dari abstraksi-abstraksi data yang dikumpulkan tentang Kampung Organik Sebagai Model Pendidikan Lingkungan Hidup Berbasis Masyarakat Bagi Anak Usia Dini berdasarkan temuan makna dalam latar yang dialami. Pendidikan anak usia dini yang menjadi objek penelitian adalah pada kelurahan dan desa yang mengembangkan kampung organik yang ada di Jawa Tengah.

Prinsip penelitian kualitatif menekankan bahwa setiap temuan (sementara) dilandaskan pada data, sehingga temuan itu semakin tersahihkan sebelum dinobatkan sebagai teori (Alwasilah, 2003:102). Desain penelitian kualitatif berfokus pada fenomena tertentu yang tidak memiliki generalizability dan comparability, tetapi memiliki internal validity dan contextual understanding. Apa yang dilakukan (action) peneliti untuk mencapai tujuan penelitian itu pada garis besarnya ada empat, yaitu (1) membangun keakraban dengan responden, (2) penentuan sampel, (3) pengumpulan data, dan (4) analisis data. Penelitian ini tidak sekedar menyangkut pengetahuan yang dapat dibahasakan (propotional knowledge), melainkan juga menyangkut pengetahuan yang tidak dapat dibahasakan (tacit knowledge), yang hampir tidak mungkin diperoleh lewat pendekatan rasionalitas (Lincoln dan Guba dalam Alwasilah, 2003:103). Kasus yang diteliti adalah Kampung Organik Sebagai Model Pendidikan Lingkungan Hidup Berbasis Masyarakat Bagi Anak Usia Dini di kelurahan dan desa yang menerapkan program kampung organik yang memiliki latar belakang yang khas. Meskipun rancangan penelitian ini akan dilakukan secara bertahap, namun dalam peristiwa-peristiwa (event) khusus pengamatan dilakukan secara simultan. Berdasarkan temuan konseptual dari kelurahan/desa tersebut, selanjutnya dilakukan analisis komparasi dan pengembangan konseptual, untuk mendapat abstraksi tentang karakteristik Kampung Organik Sebagai Model Pendidikan Lingkungan Hidup Berbasis Masyarakat Bagi Anak Usia Dini tersebut. Sejalan dengan rancangan penelitian kualitatif, penelitian ini berusaha memahami makna peristiwa serta interaksi orang dalam situasi tertentu. Untuk dapat memahami makna peristiwa dan interaksi orang, digunakan orientasi teoritik atau perspektif teoritik dengan pendekatan fenomenologis (phenomenological approach). Pendekatan ini ditetapkan dengan mengamati fenomena-fenomena dunia konseptual subjek yang diamati melalui tindakan dan 
pemikirannya guna memahami makna yang disusun oleh subjek di sekitar kejadian seharihari.

Program penelitian ini secara bertahap akan dilakukan dengan kegiatan-kegiatan sebagai berikut :

1) Melakukan studi pustaka secara lintas disiplin ilmu dan melakukan analisis kritis terhadap hasil-hasil penelitian terdahulu yang relevan dengan tema penelitian.

2) Merancang dan melaksanakan penelitian pendahuluan untuk menghasilkan deskripsi lengkap tentang pengembangan Kampung Organik Sebagai Model Pendidikan Lingkungan Hidup Berbasis Masyarakat Bagi Anak Usia Dini.

3) Berdasarkan pengembangan pendidikan karakter yang ada sekarang (yang diterapkan di sekolah-sekolah) dan sejumlah teori yang relevan, disusun (dikembangkan) suatu prototype Kampung Organik Sebagai Model Pendidikan Lingkungan Hidup Berbasis Masyarakat Bagi Anak Usia Dini.

4) Melakukan seminar lokakarya dengan pakar yang relevan dan praktisis tentang prototype Kampung Organik Sebagai Model Pendidikan Lingkungan Hidup Berbasis Masyarakat Bagi Anak Usia Dini. Target dari seminar lokakarya ini adalah tersusunnya "Buku Kampung Organik Sebagai Model Pendidikan Lingkungan Hidup Berbasis Masyarakat Bagi Anak Usia Dini ", yang disosialisasikan pada kelurahan/desa sebagai acuan untuk penyelenggaraan pendidikan lingkungan hidup berbasis masyarakat untuk anak usia dini.

5) Melakukan sosialisasi pengembangan Kampung Organik Sebagai Model Pendidikan Lingkungan Hidup Berbasis Masyarakat Bagi Anak Usia Dini.

6) Melakukan ujicoba untuk mengetahui tingkat efektivitas Kampung Organik Sebagai Model Pendidikan Lingkungan Hidup Berbasis Masyarakat Bagi Anak Usia Dini yang dikembangkan dalam penyelenggaraan pendidikan lingkungan hidup.

7) Melakukan revisi pengembangan Kampung Organik Sebagai Model Pendidikan Lingkungan Hidup Berbasis Masyarakat Bagi Anak Usia Dini berdasarkan hasil ujicoba sebagai hasil final dari program penelitian yang dilakukan.

Penelitiaan ini bersifat multi years, yang dirancang dalam tiga tahap kegiatan. Pada tahun pertama, dilakukan penelitian untuk memetakan kebutuhan pengembangan model dan perangkat pembelajaran melalui needs analysis/needs assessment untuk merumuskan rancang bangun model. Tahun kedua, dilakukan aplikasi, evaluasi, dan penentuan model final, serta merintis kampung organik. Tahun ketiga, dilakukan implementasi model final dalam pengembangan Kampung Organik Sebagai Model Pendidikan Lingkungan Hidup Berbasis Masyarakat Bagi Anak Usia Dini.

Kampung Organik Sebagai Model Pendidikan Lingkungan Hidup Berbasis Masyarakat Bagi Anak Usia Dini (yang meliputi: kurikulum, silabus, RPP, bahan ajar, media pembelajaran, alat evaluasi pembelajaran), pendidik atau instruktur dan peserta didik yang diambil sampel kabupaten/kota sejumlah 2 yaitu Kota Semarang dan Kota Magelang. Pada masing-masing kabupaten/kota diambil sampel 2 kelurahan yaitu kelurahan yang ditunjuk sebagai piloting project untuk penyelenggara kampung organik. Hal ini dilakukan karena selama penelitian, peneliti ingin mendalami secara cermat bagaimana pelaksanaan Kampung Organik Sebagai Model Pendidikan Lingkungan Hidup Berbasis Masyarakat Bagi Anak Usia Dini. Kelurahan tersebut adalah Kelurahan Krobokan, Kota Semarang dan Kelurahan Tidar, Kota Magelang.

1) Sumber sekunder adalah penyelenggara program Kampung Organik Sebagai Model Pendidikan Lingkungan Hidup Berbasis Masyarakat Bagi Anak Usia Dini yang dipandang mendukung sumber data primer, literatur, foto-foto kegiatan, dan dokumen lain dari kelurahan penyelenggara kampung organik yang diharapkan dapat memberikan informasi tentang masalah yang diteliti. Teknik pengumpulan data dalam penelitian ini adalah:

a) Observasi non partisipan yang dilakukan secara terfokus dan seksama dengan instrumen lembar observasi yang terstruktur menggunakan skala untuk memperoleh data yang berkenaan dengan proses pembelajaran dan perangkat pembelajaran yang telah digunakan pada program pendidikan lingkungan hidup berbasis masyarakat. Pencatatan hasil amatan diikuti dengan perekaman pembelajaran melalui kamera video dan foto.

b) Wawancara mendalam (in-depth interviewing) dengan instrumen pedoman wawancara terbuka dilakukan untuk menjaring data-data dari informan kunci dengan struktur yang fleksibel agar 
informasi yang diperoleh memiliki kedalaman yang cukup. Wawancara dilakukan kepada pendidik, peserta didik dan penyelenggara program kampung organik.

c) Angket dengan instrumen kuesioner tertutup untuk melengkapi data yang tidak dapat diperoleh melalui wawancara mendalam dari informan kunci.

d) Studi dokumenter, dilakukan pada dokumen yang berkaitan dengan permasalahan penelitian, termasuk penelaahan terhadap sumber pustaka.

Keabsahan data dalam penelitian ini diupayakan dengan cara: (a) uji kredibilitas yang meliputi trianggulasi, ketekunan pengamatan, diskusi dengan teman sejawat; (b) uji transferbilitas dengan menyajikan data yang mudah dipahami, laporan secara rinci; (c) uji dependabilitas dengan melakukan audit terhadap keseluruhan proses penelitian; (d) uji konfirmabilitas, antara hasil dengan proses penelitian.

Penelitian ini difokuskan pada Kampung Organik Sebagai Model Pendidikan Lingkungan Hidup Berbasis Masyarakat Bagi Anak Usia Dini. Aspek yang menjadi fokus penelitian adalah perencanaan, pengorganisasian, pelaksanaan dan evaluasi program kampung organik. Berdasarkan fokus penelitian tersebut, maka lokasi penelitian ditentukan secara purposif, dengan pertimbangan karakteristik wilayah atau daerah dan kelayakan informasi yang diperlukan. Lokasi penelitian dibedakan atas kondisi geografis yang meliputi: daerah pantai, pegunungan dan dataran. Pemilihan ini dimaksudkan untuk memperoleh data yang dapat menggambarkan pelaksanaan proses pembelajaran dari beberapa tipe kharakteristik sasaran didik, dan pada pihak lain untuk memudahkan peneliti dalam mengkaji obyek penelitian secara terfokus.

Analisis data dilakukan secara deskriptif kualitatif (Miles dan Huberman, 1992) dan analitik menggunakan uji paired t- test pada tingkat signifikansi 0,05 (Wahyono, 2006).

1) Analisis deskriptif kualitatif, digunakan untuk menganalisis data dan informasi yang diperoleh dari studi pendahuluan dengan metode survey, proses pengembangan rancangan model, serta hasil uji coba model dari pakar melalui teknik Delphi. Penggunaan analisis deskriptif kualitatif dimaksudkan untuk memperoleh gambaran tentang kampung organik sebagai model pendidikan lingkungan hidup yang telah dilakukan saat ini, penilaian kebutuhan pengembangan model pembelajaran. Analisis deskriptif juga digunakan untuk menafsirkan hasil analisis data kuantitatif dan memperoleh gambaran tentang kelemahan-kelemahan model yang divalidasi dan diuji cobakan di lapangan, sehingga hasilnya dapat digunakan sebagai dasar untuk merevisi dan mengembangkan model.

2) Analisis kuantitatif, digunakan untuk mengetahui tingkat efektivitas model yang diuji coba lapangan. Tingkat keefektivan Kampung Organik Sebagai Model Pendidikan Lingkungan Hidup Berbasis Masyarakat Bagi Anak Usia Dini ditunjukkan melalui perbandingan rerata kemampuan peserta didik antara sebelum dengan sesudah menerapkan model pendidikan lingkungan hidup berbasis masyarakat, dilihat dari aspek tingkat kognitif, afektif dan psikomotorik. Teknik analisis yang digunakan adalah statistika uji t-test berpasangan. Penggunaan uji t-test berpasangan disebabkan karena data yang diperoleh berasal dari proses pengukuran pada kelompok sampel (kelompok eksperimen) yang dilakukan dua kali pengukuran, yakni pre-test dan post-test. Melalui uji t-test berpasangan ini akan dapat diketahui pengaruh pengembangan model pembelajaran yang dilaksanakan terhadap kemampuan pengetahuan, sikap, dan keterampilan anak didik. Selanjutnya, pengelolaan dan analisis data kuantitatif digunakan program paket statistika Statistical Package for Social Sciences (SPSS) relese 16 (Wahyono, 2006).

\section{HASIL DAN PEMBAHASAN}

Dalam mengelola lingkungan, kelurahan Krobokan sudah menjadi leading bagi kelurahankelurahan lainnya di Kota Semarang. Hal ini terutama dimotori oleh pak Lurah yang punya hobi menanam tanaman. Berawal dari hoby, pak lurah menanam berbagai tanaman organik dan tanaman langka. Halaman rumahnya disulap menjadi kebun dan tanaman obat sehingga terlihat hijau dan asri. Walaupun wilayah kelurahan Krobokan ada ditengah perkotaan, namun suasana asri dan hijau sangat terasa. Ini yang menjadikan kelurahan Krobokan dikenal sebagai kampung organik. 
Pak lurah mendorong semua warganya untuk gemar menanam agar mereka dapat mendapatkan manfaat. Minimal kebutuhan akan sayur mayur bisa dipenuhi dari tanaman yang mereka tanam di halaman rumah mereka. Walaupun kebanyakan warga hanya memiliki lahan sempit bahkan ada yang tidak memiliki lahan sama sekali, namun hal ini tidak menjadikan pak lurah bosan untuk mengajak warganya menanam tanaman organik.

Setiap warga yang ingin menanam tanaman, mereka diberi penyuluhan mengenai cara menanam dan memelihara tanaman yang baik. Bagi warga yang ingin menanam tanaman namun tidak memiliki lahan, mereka diberi penyuluhan mengenai cara tanam hidroponik dan menanam tanaman di vertical land. Tanaman yang ditanam diutamakan tanaman yang memiliki manfaat langsung misalnya sayur mayur, cabe, buah-buahan, tanaman untuk pengusi nyamuk, dll. Hal ini dilakukan agar warga langsung dapat memetik manfaat dari menanan tanaman, terutaman jika harga cabe mahal, masyarakat sangat terbantu karena mereka tinggal memetik cabe yang sudah mereka tanam. Untuk tanaman pengusir nyamuk, sengaja pak lurah menggalakkan agar masyarakat bisa terhindar dari demam berdarah. Tanaman seperti lavender, kemangi, serai wangi dan lidah buaya merupakan beberapa jenis tanaman yang berguna mengusir nyamuk. Dengan demikian, apa yang dilakukan warga kelurahan Krobokan mendukung program pemerintah mengenai pencegahan demam berdarah dengan cara menjaga lingkungan. Cara pencegahan nyamuk penyebab demam berdarah dengan cara menanam tanaman pengusir nyamuk, lebih efektif dan sehat. Manfaat lain adalah, biayanya lebih murah, lingkungan jadi sehat dan asri.

Saat ini hampir seluruh warga menaman tanaman sehingga lingkungan terlihat asri dan indah, tidak gersang walau berada di tengah perkotaan. Sehingga kelurahan Krobokan sering ikut dalam lomba mengenai lingkungan. Untuk lomba kampung bersih, kelurahan Krobokan meraih juara 1 tingkat propinsi.

Selain menanam tanaman organik, pak lurah juga mendorong warganya untuk mengelola sampah. Sampah merupakan masalah yang dihadapi hampir seluruh masysarakat di Indonesia maupun dunia. Rata-rata setiap harinya kota-kota besar di Indonesia menghasilkan puluhan ton sampah. Sampah-sampah itu diangkut oleh truk-truk khusus dan dibuang atau ditumpuk begitu saja di tempat yang sudah disediakan tanpa diapa-apakan lagi. Dari hari ke hari sampah itu terus menumpuk dan terjadilah bukit sampah seperti yang sering kita lihat. Sampah yang menumpuk itu, sudah tentu akan mengganggu penduduk di sekitarnya. Selain baunya yang tidak sedap, sampah sering dihinggapi lalat. Dan juga dapat mendatangkan wabah penyakit. Walaupun terbukti sampah itu dapat merugikan, tetapi ada sisi manfaatnya. Hal ini karena selain dapat mendatangkan bencana bagi masyarakat, sampah juga dapat diubah menjadi barang yang bermanfaat. Kemanfaatan sampah ini tidak terlepas dari penggunaan ilmu pengetahuan dan teknologi dalam menanganinya. Sampah Organik adalah merupakan barang yang dianggap sudah tidak terpakai dan dibuang oleh pemilik/pemakai sebelumnya, tetapi masih bisa dipakai kalau dikelola dengan prosedur yang benar. Organik adalah proses yang kokoh dan relatif cepat, maka tanda apa yang kita punya untuk menyatakan bahwa bahan-bahan pokok kehidupan. Sampah organik adalah sampah yang bisa mengalami pelapukan (dekomposisi) dan terurai menjadi bahan yang lebih kecil dan tidak berbau (sering disebut dengan kompos). Kompos merupakan hasil pelapukan bahan-bahan organik seperti daun-daunan, jerami, alang-alang, sampah, rumput, dan bahan lain yang sejenis yang proses pelapukannya dipercepat oleh bantuan manusia Sampah yang berasal dari pemukiman umumnya sangat beragam, tetapi secara umum minimal $75 \%$ terdiri dari sampah organik dan sisanya anorganik.

Kelurahan Krobokan sendiri sudah mulai menggalakan pendaur ulangan sampah, khusunya sampah organik yaitu daun-daun pohon yang sudah jatuh. Daun-daun ini diolah menjadi pupuk kompos, tetapi sebelum menjadi pupuk kompos. Daun-daun ini di giling terlebih dahulu dengan menggunakan mesin penggiling sampah. Hal ini dimaksudkan untuk agar daun menjadi potonganpotongan yang kecil, sehingga apabila dimasukan ke dalam tong composer potongan daun tersebut 
lebih cepat menjadi pupuk. Kompos yang sudah jadi tersebut langsung digunakan untuk menyuburkan tanaman-tanaman yang ada di warung hidup di kelurahan krobokan.

Untuk penataan lingkungan, agar kebersihan dan keasrian lingkungan terjaga, pak lurah menerapkan peraturan adanya lingkungan terbuka yang digunakan untuk penghijauan. Selain itu, di pinggir-pinggir jalan diberi tanaman yang ditanam di pot. Selain itu, penataan dan pengelolaan selokan dan saluran air dilakukan secara teratur. Untuk pengelolaannya diberikan kepada masing-masing rt sehingga menjaga kebersihan lingkungan menjadi tanggungjawab bersama. Dengan demikian, diharapkan tidak ada selokan yang kotor dan tersumbat yang menjadikannya sarang nyamuk dan sumber penyakit. Kesadaran masyarakat akan pentingnya menjaga lingkungan agar selalu bersih dan sehat sudah sangat tinggi. Sehingga tidak salah jika kelurahan Krobokan dikukuhkan sebagai kampung organik dan kampung percontohan untuk kelurahan di wilayah perkotaan.

\section{Pendidikan Lingkungan Bagi Anak Usia Dini}

Fase pra sekolah adalah fase yang akan di alami setiap anak setelah masa menyusui. Pada fase ini merupakan masa eksplorasi bagi anak yang mengalami perkembangan cepat dalam berbicara, ingin selalu bergerak, senantiasa ingin memiliki sesuatu secara egois. Fase para sekolah yaitu usia antara 3 sampai 6 tahun dan merupakan bagian dari anak usia dini yang berada pada rentangan usia lahir sampai 6 tahun. Pada usia ini secara terminologi disebut sebagai anak usia pra sekolah.

Untuk mengetahui bagaimana pelaksanaan pendidikan lingkungan pada anak usia dini, penelitian melakukan penelitian di tiga sekolah yang berbeda yaitu :

\section{a. TK Negeri Pembina Kota Semarang}

Sebagai sekolah percontohan, TK Negeri Pembina Kota Semarang berusaha untuk selalu menjadi terdepan dalam menanamkan karakter yang baik bagi siswa. Penanaman karakter cinta tanah air salah satunya adalah menjaga lingkungan. Ada beberapa hal yang dilakukan yaitu mengajarkan pada anak untuk menjaga lingkungan, membuang sampah pada tempatnya, menjaga kebersihan diri dan mengajak anak-anak untuk membuat alat peraga/media pendidikan dari sampah.

Untuk penanaman karakter menjaga lingkungan melalui pembiasaan, guru sebagai role model akan memberi contoh dengan jalan mengambil sampah yang berserak untuk kemudian dibuang ke tempat sampah, membuang sampah ke tempat sampah yang sesuai. Misalnya sampah plastik akan dibuang ke tempat sampah yang ada gambar plastiknya. Menjaga kebersihan diri dengan cara mencuci tangan. Anak-anak diberi lap yang sudah diberi nama masing-masing. Pada kegiatan cuci tangan, anak-anak diajari supaya mengantri sehingga tidak berdesak-desakkan.

Keterbatasan lahan tidak menyurutkan pihak sekolah untuk mengajarkan pentingnya menanam tanaman agar dapat menjaga lingkungan tetap lestari. Salah satunya adalah menggunakan gelas plastik bekas air mineral sebagai media tanam. Selain anak-anak tau bagaimana menanam tanaman, mereka juga memahami bahwa sampah plastik dapat digunakan sebagai tempat menyemai benih.

Satu persatu anak-anak diberi biji dan gelas plastik yang sudah diisi tanah dan diberi lubang sehingga bagus untuk dijadikan sebagai media tanam. Setelah beberapa hari biji yang disemai tumbuh menjadi tanaman. Setelah itu, baru tanaman dipindah ke tanah yang memang sudah dipersiapkan sebagai media tanam. Lahan kosong yang dimiliki oleh TK Negeri Pembina sangat terbatas, namun demikian pihak sekolah berusaha memanfaatkannya secara optimal untuk penghijauan.

b. TK Labschool Kota Semarang

Hampir sama dengan TK Negeri Pembina Kota Semarang, penanaman karakter cinta tanah air salah satunya adalah menjaga lingkungan. Hal ini sejalan dengan Universitas Negeri Semarang sebagai perguruan tinggi konservasi. Ada beberapa hal yang dilakukan yaitu mengajarkan pada anak untuk menjaga lingkungan, membuang sampah pada tempatnya, menjaga kebersihan diri dan lingkungan, menanam tanaman dan mengajak anak-anak untuk membuat alat 
peraga/media pendidikan dari sampah. Kegiatan ini melibatkan orang tua agar ada sinergi yang bagus dalam hubungan anak dan orangtua.

Untuk penanaman karakter menjaga lingkungan, guru sebagai role model akan memberi contoh dengan jalan mengambil sampah yang berserak untuk kemudian dibuang ke tempat sampah, membuang sampah ke tempat sampah yang sesuai. Misalnya sampah plastik akan dibuang ke tempat sampah yang ada gambar plastiknya. Menjaga kebersihan diri dengan cara mencuci tangan. Anak-anak diberi lap yang sudah diberi nama masing-masing. Pada kegiatan cuci tangan, anak-anak diajari supaya mengantri sehingga tidak berdesak-desakkan.

Lahan yang cukup luas menjadi salah satu keuntungan sekolah untuk melakukan penghijauan. Bahkan di TK Labschool tersedia green house yang sangat berguna untuk memberikan penanaman nilai-nilai edukatif kepada siswa mengenai pentingnya menjaga lingkungan agar terus lestari dengan jalan menanam pohon. Namun demikian, kendala terbesar yang dihadapi oleh sekolah adalah terbatasnya tenaga cleaning service. Hal ini menjadikan pihak sekolah kesulitan membersihkan daun-daun kering yang ada di atap-atap sekolah. Tentu saja hal ini tidak menyurutkan niat pihak sekolah untuk mengembangkan warung hidup yang akan dibuat di sudut sekolah. Kebetulan cleaning service yang ada sangat suka untuk menanam pohon.

c. TK An Nur Kota Semarang

An-Nur berhasil menjadi yang terbaik di Jawa Tengah, dengan meraih juara 1 PAUD berprestasi tahun 2013. Dengan predikat ini tak berarti membuatnya terlena dalam kebanggan diri. Justru amanah yag diembannya kian berat, untuk tetap menjaga mutu, mengembangkan profesionalisme dan konsistensi dalam upaya peningkatan kualitas pendidikan.PAUD/KB/TK An-Nur, yang beralamat di J1 Tapak Raya Nomor 41 Tugurejo, Kecamatan Tugu Kota Semarang ini, menerima piala juara 1, PAUD Berprestasi Jateng 2013, tepatnya pada tanggal 26 Agustus. Pada tahun lalu, juga telah meraih juara 1 tingkat Jateng untuk kategori Usaha kesehatan sekolah meraih prestasi cemerlang di tingkat yang sama. Di tahun 2012, KB/TK An Nur ini mendapatkan juara tingkat I se Jawa Tengah sebagai juara terbaik untuk kategori Unit Kesehatan Sekolah (Juara I UKS Jawa Tengah). An-Nur adalah satu-satunya sekolah yang menerapkan konsep ramah lingkungan adalah dengan dimilikinya minizoo (kebun binatang kecil) dengan berbagai macam hewan. Selain itu juga mempunyai lahan yang cukup luas dengan beranekaragam tanaman obat dan buah.

KB-TK An Nur menyediakan fasilitasfasilitas antara lain minizoo (kebun binatang mini), area /lahan perkebunan sayur dan buah, halaman yang luas serta taman pendidikan lalu lintas. Dengan fasilitas-fasilitas tersebut siswa-siswi KB-TK An Nur akan mendapatkan pengalaman langsung dengan mengeksplorasi lingkungannya. Dari pendidikan yang diterapkan di KB-TK An Nur ini diharapkan akan melahirkan generasi yang sholeh-sholehah, kreatif, cinta budaya dan lingkungan. Setelah berhasil memenangkan Lomba Sekolah Sehat (LSS) mulai dari Tingkat Kecamatan, Tingkat Kota, Tingkat Karesidenan, dan Tingkat Provinsi, hari Senin tanggal 18 Juni 2012 kemarin TK An Nur menjadi duta Provinsi Jawa Tengah untuk mengikuti Lomba Sekolah Sehat (LSS) Tingkat Nasional tahun 2012.

Pada proses pembelajaran lingkungan pada anak, merupakan salah satu wujud dari materi cinta tanah air. Pembiasaan hidup bersih dan sehat sejak dini merupakan dasar bagi tumbuhnya generasi yang berbudaya dan berperilaku sehat dan bersih pula. Terciptanya sekolah sehat, nyaman dan asri merupakan hasil sinergi dari berbagai unsur terkait mulai dari Tim Pembina (TP) UKS dari tingkat Kecamatan sampai dengan tingkat Provinsi, Pengurus Yayasan An Nur, masyarakat sekolah, komite sekolah, orang tua/wali murid, Puskesmas Karang anyar, BKM (Badan Keswadayaan Masyarakat) Tugurejo, BLH (Badan Lingkungan Hidup), 
Dinas Pertanian, Dinas Kebersihan dan Pertamanan Kota Semarang, dan masih banyak lagi pihak - pihak terkait. Hasilnya pada Lomba Sekolah Sehat (LSS) Tingkat Nasional ini TK An Nur menjadi juara 1 tingkat nasional.

Setiap kelas memiliki tempat cuci tangan sendiri-sendiri yang letaknya di depan ruang kelas. Hal ini dikarenakan anak-anak dibiasakan untuk cuci tangan agar terjaga kebersihannya. Selain itu, anak-anak dibiasakan untuk membuang sampah dengan memilah sampah sebelum memasukkan ke dalam tempat sampah. Ada 3 tempat sampah yang berwarna merah, kuning dan hijau.

Sesuai dengan warnanya, tempat sampah hijau untuk sampah organik, kuning untuk plastik dan merah untuk sampah kaca dan kaleng dimana di tempat sampah ditempelkan apa saja sampah yang bisa mereka masukkan ke dalam tempat sampah tersebut. Anak-anak dibiasakan untuk memilah sampah yang akan dibuang ke tempat sampah sesuai dengan jenisnya

Setiap hari sampah-sampah tersebut dikumpulkan untuk diolah. Sampah organik yang berupa daun diolah menjadi kompos dengan cara melalui pengolahan komposting, untuk sampah plastik digunakan untuk membuat media pendidikan. Pengolahan komposting dilakukan sekolah dengan melibatkan siswa agar mereka dapat memahami kegunaan kompos. Sama juga untuk pengolahan sampah plastik menjadi alat peraga. Pihak sekolah juga melibatkan orang tua siswa. Kompos yang dihasilkan dari hasil komposting digunakan untuk memupuk tanaman yang sudah ditanam oleh siswa. Luas lahan sekolah sangat memungkinkan untuk dimanfaatkan menjadi warung hidup. Tentu saja hal ini menjadikan lingkungan TK An Nur menjadi tempat yang asri, rindang dan hijau sehingga setiap tahun menjadi juara sekolah sehat bahkan sampai tingkat nasional.

Berdasar kajian empiris terhadap Kampung Organik Sebagai Model Pendidikan Lingkungan Berbasis Masyarakat Bagi Anak Usia Dini Di Kota Semarang, maka rancangan model awal disusun sebagai berikut.

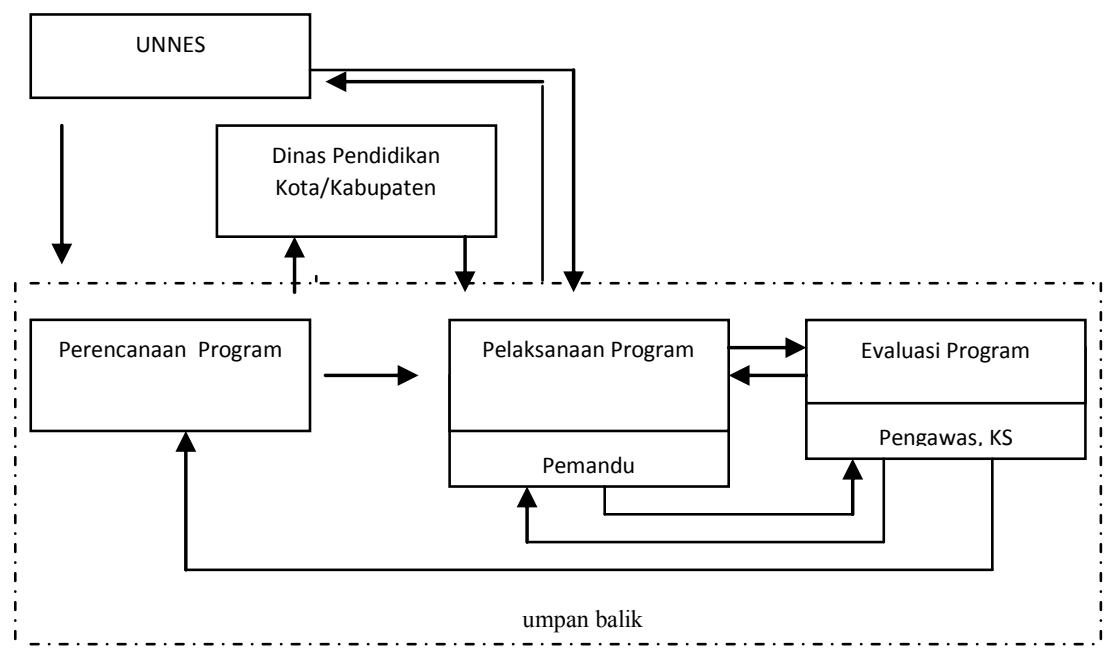

\section{Gambar 1. Model Hipotetik Kampung Organik Sebagai Model Pendidikan Lingkungan Berbasis} Masyarakat Bagi Anak Usia Dini Di Kota Semarang

Kampung Organik sebagai model pendidikan lingkungan ini dikembangkan sesuai dengan kearifan lokal yang berkembang di masyarakat. Untuk memperbaiki model yang akan diterapkan, maka dilakukan kegiatan FGD (Forum Group Discussion) dengan mengundang praktisi pendidikan lingkungan, pemerhati lingkungan, praktisi kampung organik, tokoh masyarakat, pakar Pendidikan Anak Usia Dini. Kegiatan FGD dilaksanakan pada tanggal 3 Oktober 2015 pukul 08.00 bertempat di ruang pertemuan TK Labschool Unnes, Kota Semarang. 
FGD dilaksanakan untuk menemukan model pendidikan lingkungan berbasis masyarakat bagi anak usia dini yang sesuai sehingga akan mencapai tujuan yang sudah ditetapkan secara optimal. Model ini juga untuk memudahkan pelaksanaan pendidikan lingkungan berbasis masyarakat bagi anak usia dini.

Dari model di atas, pelaksanaan pendidikan lingkungan berbasis masyarakat bagi anak usia dini di bekerjasama dengan masyarakat yang ada di lingkungan sekitar. Selain itu, hari pelaksanaannya juga menyesuaikan kemampuan masing-masing sekolah. Perangkat pembelajaran akan dibuat agar pelaksanaan dan evaluasinya lebih terarah sehingga diharapkan hasilnya memuaskan

\section{SIMPULAN}

Kelurahan krobokan merupakan kampung organik yang bisa dijadikan model pendidikan lingkungan bagi anak usia dini berbasis masayarakat.

Pendidikan lingkungan bagi anak usia dini lebih pada pembiasaan dan role model.

\section{DAFTAR PUSTAKA}

Abdurrahman, Pengantar Hukum Lingkungan Indonesia, Bandung: Citra Aditya Bakti, 1990

Budiharjo, Eko Dan Sudanti Hardjohubojo, Kota Berwawasan Lingkungan, Bandung: Anggota IKAPI, 1993

Burhan, Bungin. 2001. Metode Penelitian Kualitatif: Aktualisasi Metodologi ke Arah Ragam Varian Kontemporer. Jakarta : PT. Raja Grafindo Persada

Depdiknas. 2004. Pengembangan Karakter Sekolah. Jakarta : Depdiknas RI

Djamarah, Syaiful Bahri, Guru dan Anak Didik dalam Interaksi Edukatif, Jakarta: Rineka Cipta, 1999

Doni Koesoema. A. 2007. Pendidikan Karakter : Strategi Mendidik Anak di Jaman Global. Jakarta : Grasindo. Cetakan Pertama 